\title{
L-Triiodothyronine and L-Reverse-Triiodothyronine Generation in the Human Polymorphonuclear Leukocyte
}

\author{
Kenneth A. Woeber with the technical assistance of Betty A. Maddux, \\ Department of Medicine, Mount Zion Hospital and Medical Center and \\ University of California, San Francisco, California 94120
}

A B S T RACT Extrathyroidal monodeiodination of Lthyroxine $\left(T_{4}\right)$ is the principal source of L-triiodothyronine $\left(\mathrm{T}_{3}\right)$ and L-reverse-triiodothyronine $\left(\mathrm{rT}_{3}\right)$ production. To define some of the cellular factors involved, we examined $\mathrm{T}_{3}$ and $\mathrm{rT}_{3}$ generation from added nonradioactive $\mathrm{T}_{4}$ in human polymorphonuclear leukocytes, using radioimmunoassays to quantify the $\mathrm{T}_{3}$ and $\mathrm{rT}_{3}$ generated. Under optimum incubation conditions which included a $\mathrm{pH}$ of 6.5 in sucrose-acetate buffer, the presence of dithiothreitol as a sulfhydrylgroup protector, and incubation in an hypoxic atmosphere, significant net generation of $\mathrm{T}_{3}$ and $\mathrm{rT}_{3}$ was observed. Of the several subcellular fractions studied, the particulate fraction obtained by centrifugation at $27,000 \mathrm{~g}$ was found to possess the highest $\mathrm{T}_{3}$ - and $\mathrm{rT}_{3}$ generating activities per unit quantity of protein. With respect to $\mathrm{T}_{3}$ generation from substrate $\mathrm{T}_{4}$, the $K_{m}$ was $5 \mu \mathrm{M}$ and the $V_{\max }$ was $7.2 \mathrm{pmol} / \mathrm{min}$ per $\mathrm{mg}$ protein. Propylthiouracil, methimazole, and prior induction of phagocytosis inhibited both $\mathrm{T}_{3}$ and $\mathrm{rT}_{3}$ generation, but $\mathrm{T}_{3}$ generation was inhibited to a greater extent. $\mathrm{rT}_{3}$, in a concentration equimolar to that of substrate $T_{4}$, did not alter $T_{3}$ generation, but inhibited $T_{3}$ generation when the molar ratio of $\mathrm{rT}_{3}$ to $\mathrm{T}_{4}$ approached 10:1. Under the incubation conditions employed, particulate fractions of leukocytes obtained from five cord blood samples displayed an essentially normal relationship between $\mathrm{T}_{3}$ - and $\mathrm{r}_{3}$-generating activities, despite the distinctly divergent serum $\mathrm{T}_{3}$ and $\mathrm{rT}_{3}$ concentrations in these samples. From our findings, we draw the following conclusions: $(a)$ the human polymorphonuclear leukocyte possesses the ability to generate $T_{3}$ and $\mathrm{rT}_{3}$ from substrate $T_{4} ;(b)$ the $T_{3}$ - and $\mathrm{rT}_{3}$-generating activities are associated principally with the $27,000 \mathrm{~g}$ particulate fraction and display enzymic characteristics with a sulfhydryl-group requirement; $(c) \mathrm{T}_{3}$-generating activity appears to be more susceptible to inhibitory influences than $\mathrm{rT}_{3}$-generating activity; and $(d)$ in cord

\footnotetext{
Received for publication 5 December 1977 and in revised form 10 May 1978 .
}

blood leukocytes, the putative enzymes catalyzing $\mathrm{T}_{3}$ and $\mathrm{rT}_{3}$ generation appear to be functionally intact under the experimental conditions employed.

\section{INTRODUCTION}

After the conclusive demonstration that the bulk of L-triiodothyronine $\left(\mathrm{T}_{3}\right)^{1}$ in man arises through the extrathyroidal monodeiodination of the outer ring of $\mathrm{L}$ thyroxine $\left(T_{4}\right)(1-4)$, there has been a resurgence of interest in the use of tissue preparations for examining this phenomenon in vitro. Thus, conversion of $T_{4}$ to $\mathrm{T}_{3}$ has been demonstrated to occur in cultured human liver and kidney cells (5), in cultured human fibroblasts (6), and in freshly isolated human polymorphonuclear leukocytes $(7,8)$. These studies involved the use of radioiodine-labeled $\mathrm{T}_{4}$ as substrate, with detection and quantification of the $T_{3}$ generated by chromatographic analysis. More recently, the availability of radioimmunoassay methods for measuring $T_{3}$ has been exploited for examining $T_{4}$ to $T_{3}$ conversion in vitro. Radioimmunoassay, in addition to being more specific than chromatographic analysis, permits more precise quantification of the very small quantities of $\mathrm{T}_{3}$ generated. Using this approach, several investigators have reported the generation of $T_{3}$ from added nonradioactive $T_{4}$ by rat tissues in vitro and have examined some of the characteristics of the $T_{3}$-generating system $(9-15)$.

Recent work has demonstrated convincingly that extrathyroidal monodeiodination of $\mathrm{T}_{4}$ is also responsible for almost all L-reverse $\mathrm{T}_{3}\left(\mathrm{rT}_{3}\right)$ production $(16$, 17), monodeiodination of $T_{4}$ in this instance occurring in the inner ring. $\mathrm{rT}_{3}$ generation from $\mathrm{T}_{4}$ has also been demonstrated in rat liver in vitro $(12,13)$.

\footnotetext{
${ }^{1}$ Abbreviations used in this paper: DC, disrupted cell preparation; DTT, dithiothreitol; MMI, methimazole; N, nuclear fraction; $\mathrm{P}, 27,000-\mathrm{g}$ particulate fraction; PTU, propylthiouracil; $\mathrm{rT}_{3}$, L-reverse-T3; $\mathrm{S} 1$, initial 400-g supernate; $\mathrm{S} 2,27,000-\mathrm{g}$ supernate; $\mathrm{SH}$, sulfhydryl; $\mathrm{T} 3$, L-triiodothyronine; T4, L-thyroxine.
} 
We have previously demonstrated that intact human polymorphonuclear leukocytes, as well as the granule fraction isolated therefrom, are capable of deiodinating labeled $\mathrm{T}_{4}$ in vitro, with the generation of labeled inorganic iodide and a labeled material that remains at the origin during chromatography $(8,18)$. In addition, we detected labeled $T_{3}$ as a product of $T_{4}$ deiodination in intact cells by chromatographic analysis. However, the net quantities of $\mathrm{T}_{3}$ generated were very small, and the sensitivity of chromatographic analysis was insufficient to permit quantitative definition of the characteristics of the $T_{3}$-generating system. Accordingly, we undertook to study the generation of $T_{3}$ from added nonradioactive $T_{4}$ in the human polymorphonuclear leukocyte and its various subcellular fractions, using a specific radioimmunoassay to quantify the $T_{3}$ generated. In addition, we examined the generation of $\mathrm{rT}_{3}$, using a specific radioimmunoassay for quantifying the $\mathrm{rT}_{3}$ formed.

\section{METHODS}

Blood was collected, with $100 \mathrm{U} / 25 \mathrm{ml}$ heparin as the anticoagulant, from healthy laboratory personnel. Blood was also obtained from the umbilical cords of five full-term normal infants.

Plastic ware or siliconized glassware was used throughout. The leukocytes were isolated from the blood as described previously (8); at least $90 \%$ of the cells so obtained were polymorphonuclear, $3-8 \%$ were lymphocytes, $<2 \%$ were monocytes, and erythrocytes were virtually absent. Freshly isolated leukocytes were employed for each experiment.

Leukocyte fractionation. The isolated leukocytes were disrupted by homogenization in cold $0.34 \mathrm{M}$ sucrose. This disrupted cell preparation (DC) was centrifuged at $400 \mathrm{~g}$ for $15 \mathrm{~min}$ at $5^{\circ} \mathrm{C}$ to remove unbroken cells, nuclei, and cell debris, and the resulting supernate (S1) was saved. The pellet was washed three times with cold $0.25 \mathrm{M}$ sucrose, $0.02 \mathrm{M}$ Tris, $\mathrm{pH}$ 7.2, containing $0.5 \%$ (vol/vol) Triton X-100 (Beckman Instruments, Inc., Fullerton, Calif.) to yield a nuclear fraction (N) which was then washed and suspended in cold $0.25 \mathrm{M}$ sucrose, $0.02 \mathrm{M}$ sodium acetate, pH 6.5 (sucrose-acetate buffer). S1 and, when desired, DC in $0.34 \mathrm{M}$ sucrose were diluted with cold sodium acetate to yield final concentrations of $0.25 \mathrm{M}$ sucrose and $0.02 \mathrm{M}$ sodium acetate, $\mathrm{pH}$ 6.5. In some experiments, $\mathrm{S} 1$ was diluted with cold Tris when final $\mathrm{pH}$ values of 7.0 and above were desired. S1 was further resolved by centrifugation at $27,000 \mathrm{~g}$ for $15 \mathrm{~min}$ at $5^{\circ} \mathrm{C}$ into a particulate fraction $(P)$ and supernate $S 2$. The $P$ fraction, which has been shown to be composed of granules, plasma membrane fragments, and occasional mitochondria (19), was suspended in the sucrose-acetate buffer.

When the $\mathbf{P}$ fraction from phagocytosing cells was desired, the intact leukocytes were incubated at $37^{\circ} \mathrm{C}$ for $40 \mathrm{~min}$ before fractionation in Krebs-Ringer phosphate glucose buffer, pH 7.4, containing $0.5 \mathrm{mg} / 1 \times 10^{7}$ cells zymosan ( $\mathrm{K} \& \mathrm{~K}$ Laboratories Inc., Plainview, N. Y.) that had been opsonized by coating with fresh plasma, as described in detail previously (8). Intact leukocytes from the same isolate were preincubated concurrently in Krebs-Ringer phosphate glucose buffer alone to serve as control cells. The $P$ fraction from the phagocytosing cells was free of zymosan particles, these sedimenting with the initial $400 \mathrm{~g}$ pellet during fractionation, and the yield, in terms of protein content, was very similar to that of the $\mathbf{P}$ fraction from the control cells.

Protein concentrations of all fractions were measured according to the method of Lowry et al. (20).

Measurement of $T_{4}$ conversion to $T_{3}$ and $r T_{3}$. The cell fractions in sucrose-acetate buffer $(0.4 \mathrm{ml}$, representing the yield from $\cong 1 \times 10^{7}$ leukocytes) were added to plastic tubes containing $1 \mathrm{nmol}$ of nonradioactive $\mathrm{T}_{4}$ (Sigma Chemical Co., St. Louis, Mo.) and $50 \mathrm{nmol}$ of dithiothreitol (DTT) (Sigma Chemical Co.); the final volume of the reaction mixture was $0.5 \mathrm{ml}$, yielding final concentrations of $\mathrm{T}_{4}$ and DTT of $2 \mu \mathrm{M}$ and $100 \mu \mathrm{M}$, respectively. For each fraction a control was prepared in which the cell fraction, and the $T_{4}$ plus DTT were incubated in separate tubes and then mixed at the end of incubation. This control was used to correct for $T_{3}$ and $\mathrm{rT}_{3}$ contamination of the added nonradioactive $\mathrm{T}_{4}$, for endogenous $\mathrm{T}_{3}$ and $\mathrm{rT}_{3}$ in the cell fraction, and for cross-reactivity of the added $\mathrm{T}_{4}$ with the anti- $\mathrm{T}_{3}$ and anti-rT $\mathrm{T}_{3}$ antisera used in the radioimmunoassays. In some experiments, the reaction mixtures were enriched with small quantities of nonradioactive $\mathrm{T}_{3}$ (Sigma Chemical Co.) and $\mathrm{rT}_{3}$ (obtained through the courtesy of Dr. Robert I. Meltzer from WarnerLambert Research Institute, Morris Plains, N. J.) to assess the degradation of $\mathrm{T}_{3}$ and $\mathrm{rT}_{3}$; here, reaction mixtures enriched with identical quantities of $\mathrm{T}_{3}$ and $\mathrm{rT}_{3}$ at the end of incubation served as controls.

The tubes were incubated at $37^{\circ} \mathrm{C}$ in a metabolic shaker. An hypoxic atmosphere was attained by covering the tubes with a gassing hood and gassing with $100 \%$ nitrogen throughout the incubation period. At the end of incubation, $50 \mu \mathrm{l}$ of human serum that had been stripped of its iodothyronine content by overnight exposure to an anion exchange resin (Amberlite IRA-400, Mallinckrodt Inc., St. Louis, Mo.) was added to each tube and the contents mixed. The stripped serum was added because it facilitated pelleting of the very small amount of tissue in the reaction mixture after the addition of ethanol. This was followed by the addition of $1 \mathrm{ml}$ of cold $95 \%$ ethanol and further mixing. After standing at $5^{\circ} \mathrm{C}$ for $20 \mathrm{~min}$, the tubes were centrifuged at $1,500 \mathrm{~g}$ for $20 \mathrm{~min}$ and the supernatant ethanol extracts were collected. In eight individual reaction mixtures, this extraction procedure resulted in recovery of $90 \pm 2 \%$ (mean $\pm S E$ ) of added nonradioactive $\mathrm{T}_{3}$ and $80 \pm 2 \%$ of added nonradioactive $\mathrm{rT}_{3}$.

The concentrations of $\mathrm{T}_{3}$ and $\mathrm{rT}_{3}$ in the ethanol extracts were measured by double-antibody radioimmunoassay. For the $T_{3}$ radioimmunoassay, high specific activity $\left[{ }^{125} \mathrm{I}\right] \mathrm{T}_{3}(\cong 300$ $\mu \mathrm{Ci} / \mathrm{nmol}$ ) was obtained from Abbott Diagnostics, Diagnostic Products, North Chicago, Ill., nonradioactive $T_{3}$ from Sigma Chemical Co., and rabbit anti- $\mathrm{T}_{3}$ antiserum from Endocrine Sciences, Tarzana, Calif. Cross-reactivities of $\mathrm{rT}_{3}$ and $\mathrm{T}_{4}$ in this assay did not exceed $0.03 \%$ and $0.3 \%$, respectively. For the $\mathrm{rT}_{3}$ radioimmunoassay, $\mathrm{L}-\left[{ }^{125} \mathrm{I}\right] \mathrm{rT}_{3}$, nonradioactive $\mathrm{L}-\mathrm{rT} \mathrm{T}_{3}$, and rabbit anti-L-rT $\mathrm{T}_{3}$ antiserum were obtained from Serono Laboratories Inc., Boston, Mass. Cross-reactivities of $\mathrm{T}_{3}$ and $\mathrm{T}_{4}$ in this assay did not exceed 0.003 and $0.09 \%$, respectively. The second antibody for both assays, goat anti-rabbit gamma globulin, was obtained from Antibodies Inc., Davis, Calif. In both assays, ethanol was routinely added to the standards to yield a final concentration identical to that in the samples; addition of ethanol yielded a standard curve that was virtually superimposable on that obtained with addition of an ethanol extract of iodothyronine-free serum, the coefficients of variation in two experiments being 8.1 and $7.3 \%$. For each standard or sample a blank was prepared to contain all reagents except the anti- $\mathrm{T}_{3}$ or $-\mathrm{rT}_{3}$ antiserum. The value for percent of tracer bound in the blank was subtracted from the value in the corresponding standard or sample to correct for non- 
specific binding. The net quantity of $\mathrm{T}_{3}$ or $\mathrm{rT}_{3}$ generated in a given reaction mixture was derived by subtracting from the concentration of $\mathrm{T}_{3}$ or $\mathrm{rT}_{3}$ in the ethanol extract thereof, the concentration of $T_{3}$ or $\mathrm{rT}_{3}$ in the ethanol extract of the corresponding control in which the cell fraction and the $\mathrm{T}_{4}$ plus DTT had been kept separated until the end of incubation. All values for $\mathrm{T}_{3}$ and $\mathrm{rT}_{3}$ were corrected for recovery, using the coefficients cited earlier.

\section{RESULTS}

Determination of optimum incubation conditions. In initial experiments carried out in air, significant net generation of $\mathrm{T}_{3}$ from $1 \mathrm{nmol}$ of added nonradioactive $\mathrm{T}_{4}$ was observed after $3 \mathrm{~h}$ of incubation with DC and with $\mathrm{S} 1$ derived therefrom. $\mathrm{T}_{3}$-generating activity was found to have a $\mathrm{pH}$ optimum of 6.5 in sucrose-acetate buffer. Activity was abolished by prior boiling of the tissue for $30 \mathrm{~min}$ or by incubation at $5^{\circ} \mathrm{C}$, and was greater at $37^{\circ} \mathrm{C}$ than at room temperature. As depicted in Fig. 1, addition to the reaction mixture of DTT in a final concentration of $100 \mu \mathrm{M}$ resulted in a moderate increase in net $T_{3}$ generation when incubation was carried out in air. However, when incubation was carried out in an hypoxic atmosphere attained by gassing with $100 \% \mathrm{~N}_{2}$, the presence of $100 \mu \mathrm{M}$ DTT resulted in a great increase in net $\mathrm{T}_{3}$ generation and significant quantities of $\mathrm{rT}_{3}$ were also detected. In the case of $\mathrm{T}_{3}$, the gross quantity generated was $7.1 \pm 0.4 \mathrm{pmol}$, (mean $\pm \mathrm{SE}$, $n=6$ ), and the quantity present in the controls, representing $T_{3}$ contamination of the added $T_{4}$, endogenous $T_{3}$ in the tissue, and cross-reactivity of the added $T_{4}$ with the anti- $\mathrm{T}_{3}$ antiserum, was $3.0 \pm 0.3 \mathrm{pmol}$. Thus, the net quantity of $T_{3}$ generated was $4.1 \pm 0.3 \mathrm{pmol}$. In the case of $\mathrm{rT}_{3}$, the values for gross, control, and net quantities generated were $3.3 \pm 0.2,1.1 \pm 0.1$, and $2.2 \pm 0.1$

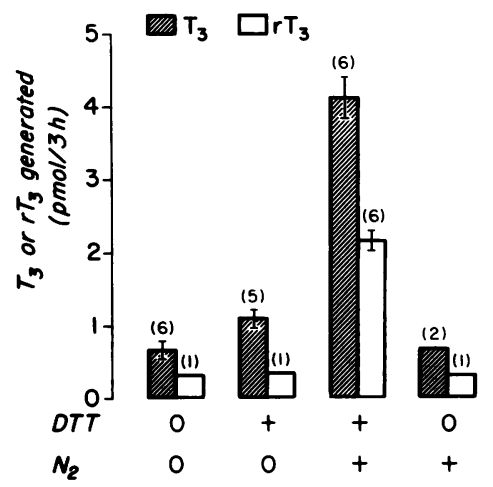

FIGURE 1 Influence of DTT and hypoxia attained by gassing with $100 \% \mathrm{~N}_{2}$ on net $\mathrm{T}_{3}$ and $\mathrm{rT}_{3}$ generation from $1 \mathrm{nmol}$ of added nonradioactive $\mathrm{T}_{4}$ by $\mathrm{S} 1$ derived from $\cong 1 \times 10^{7}$ human polymorphonuclear leukocytes and suspended in sucrose-acetate buffer, $\mathrm{pH}$ 6.5. Incubation was carried out at $37^{\circ} \mathrm{C}$. Mean $\pm \mathrm{SE}$ and number of individual reaction mixtures studied are indicated. pmol, respectively. In the absence of DTT, incubation in $\mathrm{N}_{2}$ yielded values that were very similar to those obtained in air. As depicted in Fig. 2, a linear log concentration-response relationship was demonstrable between $10 \mu \mathrm{M}$ and $1 \mathrm{mM}$ DTT, and in this concentration range, the ratios of $\mathrm{T}_{3}$ - to $\mathrm{rT}_{3}$-generating activities remained quite constant, ranging only between 2.3 and 2.6: 1 . At concentrations $\geqq 1 \mathrm{mM}$ DTT, significant generation of $T_{3}$ from $T_{4}$ was sometimes observed in the absence of tissue, and at $>1-\mathrm{mM}$ concentrations no further increase in generation by tissue was observed. Replacement of sucrose-acetate buffer with $0.14 \mathrm{M} \mathrm{KCl-0.02}$ $\mathrm{M}$ sodium acetate buffer, $\mathrm{pH} 6.5$, as the suspending medium, resulted in $54 \%$ reduction of $\mathrm{T}_{3}$ generation and $59 \%$ reduction of $\mathrm{rT}_{3}$ generation. Accordingly, sucrose-acetate buffer, $\mathrm{pH} 6.5$, enriched with $100 \mu \mathrm{M}$ DTT was routinely employed as the suspending medium, and incubation was carried out in $100 \% \mathrm{~N}_{2}$ at $37^{\circ} \mathrm{C}$.

Comparison of activity in various cell fractions. Fig. 3 depicts the net generation of $\mathrm{T}_{3}$ and $\mathrm{rT}_{3}$ from 1 nmol of added $\mathrm{T}_{4}$ after a 3-h incubation with the fractions obtained from $\cong 1 \times 10^{7}$ cells, using the optimum incubation conditions. The bulk of activity in the DC preparation was recovered in $\mathrm{S} 1$, although the nuclear fraction also possessed some activity. As depicted in Fig. 4, the bulk of activity in the $S 1$ fraction was recovered in $\mathbf{P}$ derived therefrom by centrifugation at $27,000 \mathrm{~g}$, with little activity remaining in the resulting supernate (S2). The $\mathrm{T}_{3}$ - and $\mathrm{rT}_{3}$-generating activities of $P$ fraction per unit quantity of protein were approximately four- to fivefold greater than those of the DC preparation.

Characteristics of activity of particulate fraction. The net generation of $\mathrm{T}_{3}$ and $\mathrm{rT}_{3}$ from $1 \mathrm{nmol}$ of added $\mathrm{T}_{4}$ after a 3-h incubation with $\mathrm{P}$ fraction obtained from

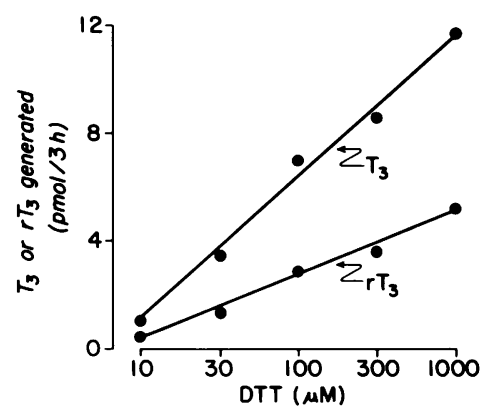

Figure 2 Net $\mathrm{T}_{3}$ and $\mathrm{rT}_{3}$ generation from $1 \mathrm{nmol}$ of added nonradioactive $T_{4}$ by $S 1$ derived from $\cong 1 \times 10^{7}$ human polymorphonuclear leukocytes as a function of the concentration of added DTT. The suspending medium was sucroseacetate buffer, pH 6.5, and incubation was carried out in $100 \% \mathrm{~N}_{2}$ at $37^{\circ} \mathrm{C}$. Each point represents the mean of duplicate determinations of an individual reaction mixture; very similar results were obtained in a second experiment. 


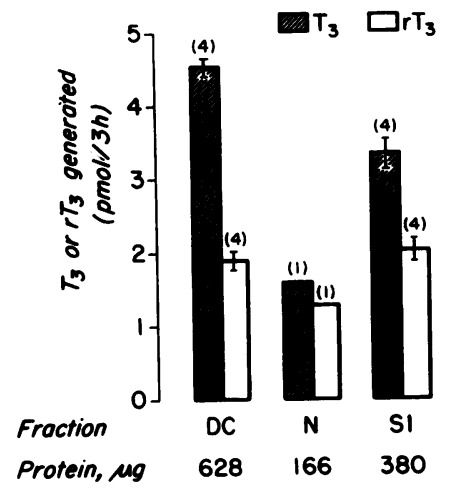

Figure 3 Comparison of net $\mathrm{T}_{3}$ and $\mathrm{rT}_{3}$ generation from 1 nmol of added nonradioactive $\mathrm{T}_{4}$ by various fractions obtained from $\cong 1 \times 10^{7}$ human polymorphonuclear leukocytes. In this and all the subsequent experiments depicted, the suspending medium was sucrose-acetate buffer, $\mathrm{pH} 6.5$, enriched with $100 \mu \mathrm{M}$ DTT, and incubation was carried out in $100 \% \mathrm{~N}_{2}$ at $37^{\circ} \mathrm{C}$. Mean $\pm \mathrm{SE}$ and number of individual reaction mixtures studied are indicated.

$\cong 1 \times 10^{7}$ cells, was much greater at $\mathrm{pH} 6.5$ than at $\mathrm{pH}$ 7.4 or 9.0. The pmol of $\mathrm{T}_{3}$ and $\mathrm{rT}_{3}$ generated were, respectively, 3.7 and 2.4 at $\mathrm{pH} 6.5,1.2$ and 0.9 at $\mathrm{pH}$ 7.4, and 1.1 and 1.2 at $\mathrm{pH} 9.0$. Using the optimum incubation conditions at $\mathrm{pH} 6.5,5.0 \pm 1.3 \%$ (mean $\pm \mathrm{SE}$ ) of added nonradioactive $\mathrm{T}_{3}$ and $8.6 \pm 1.4 \%$ of added nonradioactive $\mathrm{rT}_{3}$ were degraded after $3 \mathrm{~h}$ in 10 individual reaction mixtures. As depicted in Fig. 5 , net $T_{3}$ generation appeared to increase as a linear function of time during the first $2 \mathrm{~h}$ of incubation, and then appeared to level off during the $3 \mathrm{rd} h$. In the case of $\mathrm{rT}_{3}$, net generation increased with time, but did not appear to level off during the $3 \mathrm{rd} h$. In an experiment in which incubation was carried out for $20 \mathrm{~h}$, the net quantity of $\mathrm{T}_{3}$ generated after $20 \mathrm{~h}$ was only $37 \%$ greater than that after $3 \mathrm{~h}$, whereas the net quantity of $\mathrm{rT}_{3}$ gen-

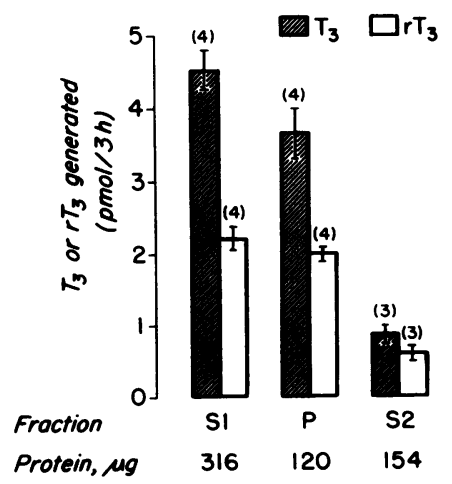

Figure 4 Comparison of net $\mathrm{T}_{3}$ and $\mathrm{rT}_{3}$ generation from 1 nmol of added nonradioactive $T_{4}$ by $S 1$ and its constituent $P$ fraction and $\mathrm{S} 2$ derived from $\cong 1 \times 10^{7}$ human polymorphonuclear leukocytes. Mean $\pm S E$ and number of individual reaction mixtures studied are indicated.

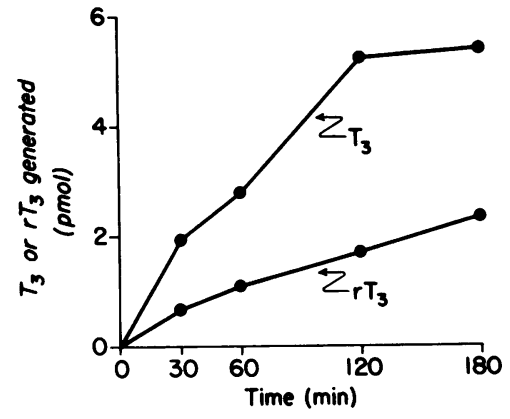

Figure 5 Time-course of net $\mathrm{T}_{3}$ and $\mathrm{rT}_{3}$ generation from 1 nmol of added nonradioactive $T_{4}$ by the $P$ fraction derived from $\cong 1 \times 10^{7}$ human polymorphonuclear leukocytes. Each point represents the mean of duplicate determinations of an individual reaction mixture.

erated was $116 \%$ greater than that after $3 \mathrm{~h}$. Fig. 6 depicts the $P$ fraction dependence of net $T_{3}$ and $\mathrm{rT}_{3}$ generation from $1 \mathrm{nmol}$ of added $\mathrm{T}_{4}$ for a 3-h incubation period. Net generation of both $\mathrm{T}_{3}$ and $\mathrm{rT}_{3}$ increased with an increase in the concentration of $P$ fraction in the reaction mixture, and at all concentrations, the ratios of $\mathrm{T}_{3}$ - to $\mathrm{rT}_{3}$-generating activities remained constant at $2: 1$. Here, the highest concentration of $P$ fraction of $326 \mu \mathrm{g} / \mathrm{ml}$ represented the mean yield of fraction (163 $\mu \mathrm{g})$ from $\cong 1 \times 10^{7}$ cells suspended in a final volume of $0.5 \mathrm{ml}$. Fig. 7 depicts the $T_{4}$-concentration dependence of net $T_{3}$ generation. A double reciprocal plot of the net quantity of $T_{3}$ generated after $15 \mathrm{~min}$ incubation with $18 \mu \mathrm{g}$ of $P$ fraction as a function of the concentration of added $T_{4}$, suggested that $T_{3}$ generation conforms to Michaelis-Menten kinetics with a 5- $\mu \mathrm{M} K_{m}$ and a 7.2-pmol $V_{\max }$ of $T_{3}$ generated per minute per milligram protein. In the case of $\mathrm{rT}_{3}$, generation was greater with higher concentrations of added $T_{4}$, but the data obtained in several experiments could not be plotted in the double reciprocal manner. Consequently, reliable values for $K_{m}$ and $V_{\max }$ could not be derived.

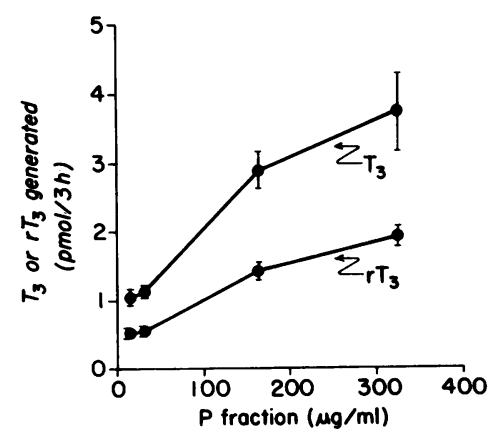

Figure 6 Net $\mathrm{T}_{3}$ and $\mathrm{rT}_{3}$ generation from $1 \mathrm{nmol}$ of added nonradioactive $T_{4}$ as a function of the concentration of $P$ fraction. Values represent mean $\pm \mathrm{SE}$ of four individual reaction mixtures. 


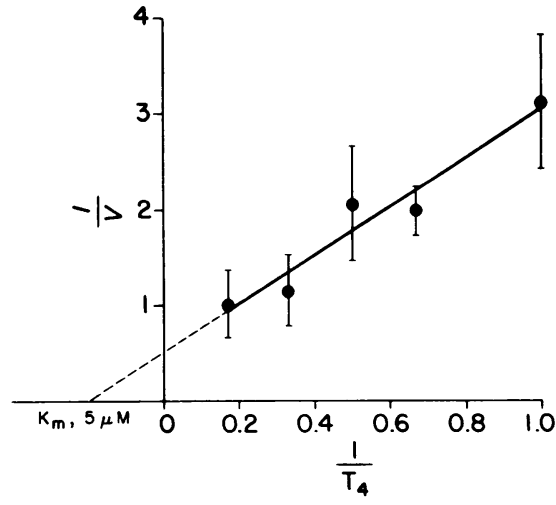

Figure $7 \quad T_{4}$-concentration dependence of net $T_{3}$ generation by $18 \mu \mathrm{g} P$ fraction. $V$ measured in picomoles of $\mathrm{T}_{3}$ generated per 15 minute, and $T_{4}$ measured in micromolar concentrations. Values represent mean $\pm \mathrm{SE}$ of three individual reaction mixtures.

Factors affecting activity of particulate fraction. Table I summarizes the influence of several factors on the $T_{3^{-}}$and $\mathrm{rT}_{3}$-generating activities of $\mathrm{P}$ fraction obtained from $\cong 1 \times 10^{7}$ cells, employing $1 \mathrm{nmol}$ of added $\mathrm{T}_{4}$, a 3-h incubation period, and the optimum incubation conditions. Addition to the reaction mixture of either propylthiouracil (PTU) or methimazole (MMI) in concentrations of 10,30 , and $100 \mu \mathrm{M}$ was accompanied by a progressive inhibition of net $\mathrm{T}_{3}$ and $\mathrm{rT}_{3}$ generation. Similarly, prior induction of phagocytosis in the leukocytes was accompanied by inhibition of the $T_{3}$-and $\mathrm{rT}_{3}$-generating activities of the subsequently isolated $\mathrm{P}$ fraction. In the foregoing circumstances, $\mathrm{T}_{3}$ generation appeared to be disproportionately depressed, as judged from the decreases in the ratio of $\mathrm{T}_{3}$ to $\mathrm{rT}_{3}$ generated. The presence of $100 \mu \mathrm{M}$ PTU, $100 \mu \mathrm{M}$ MMI, or P fraction from phagocytosing cells did not significantly affect the degradation of added nonradioactive $T_{3}$ or $\mathrm{rT}_{3}$. Thus, the inhibition of net $T_{3}$ and $\mathrm{rT}_{3}$ generation in the foregoing circumstances could not be attributed to increased degradation of product generated. Also presented in Table $I$ are the results of an experiment in which the influence of added $\mathrm{rT}_{3}$ on $\mathrm{T}_{3}$ generation was examined. Addition of $\mathrm{rT}_{3}$ in a concentration equimolar to that of the added substrate $\mathrm{T}_{4}$ did not interfere with net $\mathrm{T}_{3}$ generation, but inhibition was observed when a 10 -fold greater concentration of $\mathrm{rT}_{3}$ was employed.

Activity of particulate fraction from cord blood. Table II summarizes the results of studies in which $\mathrm{T}_{3}$ and $\mathrm{rT}_{3}$ generation from $1 \mathrm{nmol}$ of added $\mathrm{T}_{4}$ was examined with $P$ fraction of leukocytes obtained from cord blood. Also presented are the values for concurrently studied $\mathbf{P}$ fraction from adult blood, as well as the values for serum $T_{3}$ and $\mathrm{rT}_{3}$ concentrations. Incubation conditions were as outlined before. Because the yield of $P$ fraction varied among the
TABLE I

Influence of Various Factors on Net $\mathrm{T}_{3^{-}}$and $r \mathrm{~T}_{3^{-} \text {-Generating }}$ and $T_{3}$ and $r T_{3}$-Degrading Activities of Leukocyte Particulate Fraction

\begin{tabular}{|c|c|c|c|c|c|c|}
\hline \multirow{2}{*}{$\begin{array}{l}\text { Experi- } \\
\text { ment }\end{array}$} & \multirow[b]{2}{*}{ Factor } & \multicolumn{3}{|c|}{ Net generating activity } & \multicolumn{2}{|c|}{$\begin{array}{l}\text { Degrading } \\
\text { activity }\end{array}$} \\
\hline & & $T_{3}$ & $\mathrm{rT}_{3}$ & $\mathrm{~T}_{3} / \mathrm{r} \mathrm{T}_{3}$ & $\mathrm{~T}_{3}$ & $\mathrm{rT}_{3}$ \\
\hline & & \multicolumn{3}{|c|}{$\mathrm{pmol} / 3 \mathrm{~h}$} & \multicolumn{2}{|c|}{$\%$ added } \\
\hline \multirow[t]{7}{*}{1} & None & 5.6 & 2.5 & 2.2 & 5.4 & 10.2 \\
\hline & PTU, $10 \mu \mathrm{M}$ & 3.5 & 1.8 & 1.9 & - & - \\
\hline & PTU, $30 \mu \mathrm{M}$ & 3.2 & 1.5 & 2.1 & - & - \\
\hline & PTU, $100 \mu \mathrm{M}$ & 1.3 & 1.2 & 1.1 & 7.3 & 11.0 \\
\hline & MMI, $10 \mu \mathrm{M}$ & 2.3 & 1.3 & 1.8 & - & - \\
\hline & $\mathrm{MMI}, 30 \mu \mathrm{M}$ & 1.5 & 1.0 & 1.5 & - & - \\
\hline & $\mathrm{MMI}, 100 \mu \mathrm{M}$ & 1.1 & 0.8 & 1.4 & 0 & 8.0 \\
\hline \multirow[t]{2}{*}{2} & None & 7.4 & 3.0 & 2.5 & 3.5 & 5.1 \\
\hline & Phagocytosing & 3.2 & 1.9 & 1.7 & 2.9 & 10.3 \\
\hline \multirow[t]{3}{*}{3} & None & 3.8 & - & - & - & - \\
\hline & $\mathrm{rT}_{3}, 2 \mu \mathrm{M}$ & 4.5 & - & - & - & - \\
\hline & $\mathrm{rT}_{3}, 20 \mu \mathrm{M}$ & 2.6 & - & - & - & - \\
\hline
\end{tabular}

different blood samples, values for $T_{3}$ and $\mathrm{rT}_{3}$ generation per $100 \mu \mathrm{g}$ protein are also presented.

In all five cord blood samples, the expected great increase in serum $\mathrm{rT}_{3}$ concentration and modest decrease in serum $T_{3}$ concentration relative to adult blood were observed. For the group of five cord samples as a whole, $\mathrm{T}_{3^{-}}$and $\mathrm{rT}_{3^{-}}$-generating activities per unit quantity of $P$ fraction did not differ significantly from those for adult blood. In addition, the ratios of $\mathrm{T}_{3}$-generating activity to $\mathrm{rT}_{3}$-generating activity, which are independent of the quantity of $P$ fraction employed, were very similar in the cord and adult samples.

\section{DISCUSSION}

In the present study, we have provided evidence that the human polymorphonuclear leukocyte possesses the ability to generate both $T_{3}$ and $\mathrm{rT}_{3}$ from substrate $T_{4}$. The $\mathrm{pH}$ optimum for $\mathrm{T}_{3}$ generation was found to be 6.5 which is very similar to that observed by others in rat liver homogenate (12) or rat liver microsomes (13). In contrast to these latter studies in which no $\mathrm{rT}_{3}$ generation could be detected at $\mathrm{pH} 6.5$, this only being detected at $\cong \mathrm{pH} 9.0$, we found significant quantities of $\mathrm{rT}_{3}$ at $\mathrm{pH}$ 6.5. In fact, the quantity of $\mathrm{rT}_{3}$ generated at $\mathrm{pH} 6.5$ exceeded that at $\mathrm{pH} 7.4$ and 9.0.

We found that DTT, a protective reagent for sulfhydryl (SH) groups (21), and an hypoxic atmosphere were prerequisites for optimum generation of both $\mathrm{T}_{3}$ and $\mathrm{rT}_{3}$. In their absence, $\mathrm{T}_{3}$ generation was greatly depressed and $\mathrm{rT}_{3}$ generation was barely detectable. The stimulatory effect of SH-group protectors was first recognized by Nakagawa and Ruegamer (22) who 
TABLE II

Comparison of Serum $T_{3}$ and $r T_{3}$ Concentrations and $T_{3^{-}}$and $r T_{3}$-Generating Activities of Leukocyte Particulate Fraction from Cord Blood and from Normal Adult Blood

\begin{tabular}{|c|c|c|c|c|c|c|c|c|c|}
\hline \multirow{2}{*}{$\begin{array}{c}\text { Experi- } \\
\text { ment }\end{array}$} & \multirow[b]{2}{*}{ State } & \multicolumn{2}{|c|}{$\begin{array}{c}\text { Serum } \\
\text { concentration }\end{array}$} & \multirow[b]{2}{*}{$P$ fraction } & \multicolumn{5}{|c|}{ Net generating activity } \\
\hline & & $T_{3}$ & $\mathrm{rT}_{3}$ & & $T_{3}$ & $\mathrm{rT}_{3}$ & $T_{3}$ & $\mathrm{rT}_{3}$ & $T_{3} / T_{3}$ \\
\hline & & \multicolumn{2}{|c|}{ ng/dl } & $\mu g$ & \multicolumn{2}{|c|}{ pmol/3 h } & \multicolumn{2}{|c|}{ pmol/3 h/100 $\mu \mathrm{g}$} & \\
\hline \multirow[t]{2}{*}{1} & Cord blood & 42 & 233 & 175 & 2.9 & 1.7 & 1.7 & 1.0 & 1.7 \\
\hline & Concurrent adult & 133 & 12 & 201 & 3.6 & 1.9 & 1.8 & 0.9 & 2.0 \\
\hline \multirow[t]{2}{*}{2} & Cord blood & 88 & 168 & 105 & 0.6 & 0.4 & 0.6 & 0.4 & 1.5 \\
\hline & Concurrent adult & 124 & 14 & 191 & 4.3 & 2.1 & 2.2 & 1.1 & 2.0 \\
\hline \multirow[t]{2}{*}{3} & Cord blood & 43 & 160 & 88 & 1.2 & 0.6 & 1.4 & 0.7 & 2.0 \\
\hline & Concurrent adult & 116 & 11 & 105 & 2.6 & 1.0 & 2.5 & 1.0 & 2.5 \\
\hline \multirow[t]{2}{*}{4} & Cord blood & 64 & 135 & 179 & 4.0 & 1.6 & 2.2 & 0.9 & 2.4 \\
\hline & Concurrent adult & 116 & 12 & 196 & 4.2 & 1.8 & 2.1 & 0.9 & 2.3 \\
\hline \multirow[t]{6}{*}{5} & Cord blood & 42 & 130 & 130 & 2.3 & 1.2 & 1.8 & 0.9 & 2.0 \\
\hline & Concurrent adult & 110 & 19 & 217 & 3.2 & 1.9 & 1.5 & 0.9 & 1.7 \\
\hline & & & & \multirow{2}{*}{\multicolumn{3}{|c|}{$\begin{array}{r}\text { Cord blood, Mean } \\
\pm S E\end{array}$}} & 1.5 & 0.8 & 1.9 \\
\hline & & & & & & & \pm 0.3 & \pm 0.1 & \pm 0.2 \\
\hline & & & & \multirow{2}{*}{\multicolumn{3}{|c|}{$\begin{array}{r}\text { Concurrent adult, Mean } \\
\pm S E\end{array}$}} & 2.0 & 1.0 & 2.1 \\
\hline & & & & & & & \pm 0.2 & \pm 0.0 & \pm 0.1 \\
\hline
\end{tabular}

demonstrated that thioglycolate caused a threefold or greater stimulation of $\mathrm{T}_{4}$ deiodination to inorganic iodide in rat liver homogenate. Recently Hüfner et al. (12) have demonstrated that mercaptoethanol enhances $\mathrm{T}_{4}$ conversion to $\mathrm{T}_{3}$ in rat liver homogenate, and Visser et al. (23) and Chopra (24) have reported a similar effect of DTT. Although, in our study, the presence of DTT in a concentration of $100 \mu \mathrm{M}$ resulted in a slight increase in $T_{3}$ generation when incubation was carried out in air, the stimulatory effect of DTT on $\mathrm{T}_{3}$ and $\mathrm{rT}_{3}$ generation was clearly evident when incubation was carried out in an hypoxic atmosphere. These findings suggest that $\mathrm{SH}$ groups either serve as cofactors or are a constituent of the putative enzymes catalyzing $\mathrm{T}_{3}$ or $\mathrm{rT}_{3}$ generation, and because such groups are readily oxidized in air to disulfides, an hypoxic atmosphere serves to maintain them in the reduced state.

The bulk of the $T_{3}$ - and $\mathrm{rT}_{3}$-generating activities in the human polymorphonuclear leukocyte was found to be associated with the particulate fraction obtained by centrifugation at $27,000 \mathrm{~g}$. This finding is consonant with our earlier work demonstrating that the leukocyte granule fraction represents the subcellular locus for the degradation of $\mathrm{T}_{4}$ to inorganic iodide and origin material (18). In this earlier work, the experimental conditions employed did not permit detection of either $\mathrm{T}_{3}$ or $\mathrm{rT}_{3}$ generation. In rat liver, on the other hand, the subcellular locus of $\mathrm{T}_{3}$ and $\mathrm{rT}_{3}$ generation has been reported to be associated with the microsomal fraction $(9,13)$, although in rat kidney, it appears to be associated with a particulate fraction comprising plasma membranes and mitochondria (15). Recently, Maciel et al. (25) have presented evidence suggesting that the plasma membrane fraction is the subcellular locus of $\mathrm{T}_{3}$-generating activity in rat liver. Accordingly, entrapment of active plasma membrane components in various subcellular fractions could account for the apparent discordance in the reported subcellular localization of $\mathrm{T}_{3}$-generating activity. Although our particulate fraction is comprised largely of neutrophil granules, the presence of plasma membrane components could be responsible for the activity observed.

The $\mathrm{T}_{3^{-}}$and $\mathrm{rT}_{3^{-}}$-generating activities of the human leukocyte displayed enzymic characteristics, including $\mathrm{pH}$ and temperature optima and tissue-concentration and time dependence. The derived value for $K_{m}$ of the putative enzyme responsible for $T_{3}$ generation was of the order of $5 \mu \mathrm{M}$. This is similar to the $K_{m}$ of the $\mathrm{T}_{3}$-generating system in rat liver and kidney homogenates $(12,14,15)$. On the other hand, the $V_{\max }$ of 7.2 pmol of $T_{3}$ generated per minute per milligram of particulate fraction was much greater than that of rat liver homogenate $(0.13 \mathrm{pmol} / \mathrm{min}$ per $\mathrm{mg})(14)$ or that of rat kidney homogenate $(0.03 \mathrm{pmol} / \mathrm{min}$ per $\mathrm{mg})(15)$, reflecting at least in part a greater degree of purification of the putative enzyme. In the case of $\mathrm{rT}_{3}$ generation, reliable values for $K_{m}$ and $V_{\max }$ could not be derived from the data obtained.

A variety of physiologic and pathologic states are 
accompanied by subnormal serum $\mathrm{T}_{3}$ concentrations and by increased serum $\mathrm{rT}_{3}$ concentrations (26), and this has led to the suggestion that inner and outer ring monodeiodination of $\mathrm{T}_{4}$ may be regulated in a reciprocal manner. PTU has been shown to result in a decrease in serum $T_{3}$ concentration and an increase in serum $\mathrm{rT}_{3}$ concentration in vivo (27) and to inhibit $T_{3}$ generation from $T_{4}$ by rat liver and kidney homogenates in vitro $(10-12,14,15)$, but its effect on $\mathrm{rT}_{3}$ generation has not been examined. In common with this earlier work, we found that PTU inhibited $\mathrm{T}_{3}$ generation and, in addition, found that $\mathrm{rT}_{3}$ generation was also inhibited, but to a lesser extent. MMI in a concentration equimolar to that of PTU was also found to inhibit both $\mathrm{T}_{3}$ and, to a lesser extent, $\mathrm{rT}_{3}$ generation by particulate fraction. This latter finding is discordant with previous reports of a lack of an effect of MMI on $T_{4}$ conversion to $T_{3}$ in vivo (27) or in vitro $(11,14$, 15). This discordance may be due to the large concentrations of MMI and the small quantity of tissue employed in our study relative to the in vivo circumstance and to the previous in vitro studies. As was the case with PTU and MMI, prior induction of phagocytosis also resulted in inhibition of both $\mathrm{T}_{3}$ and, to a lesser extent, $\mathrm{rT}_{3}$ generation by particulate fraction. Thus, none of the foregoing factors resulted in a true dissociation of $T_{3^{-}}$ and $\mathrm{rT}_{3}$-generating activities, but $\mathrm{T}_{3}$ generation appeared to be more susceptible to inhibition than $\mathrm{rT}_{3}$ generation. Because outer ring monodeiodination of $\mathrm{T}_{4}$ is involved in the degradation of $\mathrm{rT}_{3}$ as well as representing the pathway for $T_{3}$ generation whereas inner ring monodeiodination has the converse actions, a greater inhibition of outer ring monodeiodination might ultimately result in a net increase in $\mathrm{rT}_{3}$ and a net decrease in $\mathrm{T}_{3}$ in the in vivo circumstance.

$\mathrm{rT}_{3}$ has been reported to inhibit $\mathrm{T}_{4}$ conversion to $T_{3}$ in rat liver homogenate $(11,12,14)$, although the physiologic relevance of this finding has been questioned (28). We also found that $\mathrm{rT}_{3}$ inhibited $\mathrm{T}_{3}$ generation from $\mathrm{T}_{4}$, but only when the molar ratio of $\mathrm{rT}_{3}$ to $\mathrm{T}_{4}$ approached 10:1.

The very early newborn period represents a physiologic state in which serum $T_{3}$ and $\mathrm{rT}_{3}$ concentrations are distinctly divergent. Despite this divergence, we found that the $T_{3^{-}}$and $\mathrm{rT}_{3}$-generating activities of particulate fraction from cord blood leukocytes did not differ significantly from those of normal adult blood. This discordance could be interpreted as suggesting that the leukocyte is an unimportant site of $\mathrm{T}_{3}$ and $\mathrm{rT}_{3}$ generation with little influence on overall $\mathrm{T}_{3}$ and $\mathrm{rT}_{3}$ economy in vivo. On the other hand, there is an alternative explanation for our findings. Chopra (24) has recently reported that DTT restores $\mathrm{T}_{3}$-generating activity of liver homogenate from fetal sheep, and, accordingly, suggested that deficient generation of $T_{3}$ in fetal tissue was due not to a quantitative deficiency of the enzyme per se, but to the redox state of SH groups in the tissue. Because our incubation conditions required the presence of DTT for detection of significant net $\mathrm{T}_{3}$ and $\mathrm{rT}_{3}$ generation, our findings of normal activity with particulate fraction from cord blood leukocytes may reflect correction of the putative abnormality in the redox state of SH groups. Thus, if it is granted that the leukocyte is an important site of $T_{3}$ and $\mathrm{rT}_{3}$ generation, the results would suggest that, as in the case of fetal liver, the putative enzymes catalyzing $T_{3}$ and $\mathrm{rT}_{3}$ generation appear to be functionally intact in the very early newborn period.

The human polymorphonuclear leukocyte resembles other thyroid-hormone-responsive tissues in displaying a calorigenic response to thyroid hormone and in possessing saturable nuclear binding sites for $T_{3}(29)$. The present study demonstrates that this cell also has the capability of generating $T_{3}$ and $\mathrm{rT}_{3}$ from substrate $\mathrm{T}_{4}$.

\section{ACKNOWLEDGMENTS}

This study was supported in part by research grant AM-19081 from the National Institutes of Health, Bethesda, Maryland, and in part by Mount Zion Hospital and Medical Center, San Francisco, California.

\section{REFERENCES}

1. Braverman, L. E., S. H. Ingbar, and K. Sterling. 1970. Conversion of thyroxine $\left(\mathrm{T}_{4}\right)$ to triiodothyronine $\left(\mathrm{T}_{3}\right)$ in athyreotic human subjects. J. Clin. Invest. 49: 855-864.

2. Pittman, C. S., J. B. Chambers, Jr., and V. H. Read. 1971. The extrathyroidal conversion rate of thyroxine to triiodothyronine in normal man. J. Clin. Invest. 50: 11871196.

3. Surks, M. I., A. R. Schadlow, J. M. Stock, and J. H. Oppenheimer. 1973. Determination of iodothyronine absorption and conversion of L-thyroxine $\left(\mathrm{T}_{4}\right)$ to L-triiodothyronine $\left(\mathrm{T}_{3}\right)$ using turnover rate techniques. J. Clin. Invest. 52: 805-811.

4. Braverman, L. E., A. Vagenakis, P. Downs, A. E. Foster, K. Sterling, and S. H. Ingbar. 1973. Effect of replacement doses of sodium-L-thyroxine on the peripheral metabolism of thyroxine and triiodothyronine in man. J. Clin. Invest. 52: 1010-1017.

5. Sterling, K., M. A. Brenner, and V. F. Saldanha. 1973. Conversion of thyroxine to triiodothyronine by cultured human cells. Science (Wash. D. C.). 179: 1000-1001.

6. Refetoff, S., R. Matalon, and M. Bigazzi. 1972. Metabolism of L-thyroxine $\left(\mathrm{T}_{4}\right)$ and L-triiodothyronine $\left(\mathrm{T}_{3}\right)$ by human fibroblasts in tissue culture: evidence for cellular binding proteins and conversion of $\mathrm{T}_{4}$ to $\mathrm{T}_{3}$. Endocrinology. 91: 934-947.

7. Klebanoff, S. J., and W. L. Green. 1973. Degradation of thyroid hormones by phagocytosing human leukocytes. $J$. Clin. Invest. 52: 60-72.

8. Woeber, K. A., and S. H. Ingbar. 1973. Metabolism of L-thyroxine by phagocytosing human leukocytes. J. Clin. Invest. 52: 1796-1803.

9. Hesch, R. D., G. Brunner, and H. D. Söling. 1975. Conversion of thyroxine $\left(T_{4}\right)$ and triiodothyronine $\left(T_{3}\right)$ and the subcellular localization of the converting enzyme. Clin. Chim. Acta. 59: 209-213.

10. Visser, T. J., I. Van Der Does-Tobé, R. Docter, and G. Hennemann. 1975. Conversion of thyroxine into tri- 
iodothyronine by rat liver homogenate. Biochem. J. 150: 489-493.

11. Chopra, I. J. 1977. A study of extrathyroidal conversion of thyroxine $\left(\mathrm{T}_{4}\right)$ to $3,3^{\prime}, 5$-triiodothyronine $\left(\mathrm{T}_{3}\right)$ in vitro. Endocrinology. 101: 453-463.

12. Hüfner, M., M. Grussendorf, and M. Ntokalou. 1977. Properties of the thyroxine $\left(\mathrm{T}_{4}\right)$ monodeiodinating system in rat liver homogenate. Clin. Chim. Acta. 78: 251-259.

13. Höfken, B., R. Ködding, and R-D Hesch. 1977. Conversion of $T_{4}$ to $T_{3}$ and $\mathrm{rT}_{3}$ and their cytoplasmic binding: pH dependency. Clin. Chim. Acta. 78: 261-266.

14. Kaplan, M. M., and R. D. Utiger. 1978. Iodothyronine metabolism in rat liver homogenates. J. Clin. Invest. 61 : 459-471.

15. Chiraseveenuprapund, P., U. Buergi, A. Goswami, and I. N. Rosenberg. 1978. Conversion of L-thyroxine to triiodothyronine in rat kidney homogenate. Endocrinology. 102: 612-622.

16. Chopra, I. J. 1976. An assessment of daily production and significance of thyroidal secretion of $3,3^{\prime}, 5^{\prime}$-triiodothyronine (reverse $\mathrm{T}_{3}$ ) in man. J. Clin. Invest. 58: 32-40.

17. Gavin, L., J. Castle, F. McMahon, P. Martin, M. Hammond, and R. R. Cavalieri. 1977. Extrathyroidal conversion of thyroxine to $3,3^{\prime}, 5^{\prime}$-triiodothyronine (reverse$\mathrm{T}_{3}$ ) and to 3,3'5-triiodothyronine $\left(\mathrm{T}_{3}\right)$ in humans. $J$. Clin. Endocrinol. Metab. 44: 733-742.

18. Woeber, K. A. 1976. A granule-associated L-thyroxine deiodinating system in the human leukocyte. Endocrinology 98: 802-806.

19. Babior, B. M., J. T. Curnutte, and B. J. McMurrich. 1976. The particulate superoxide-forming system from human neutrophils. J. Clin. Invest. 58: 989-996.

20. Lowry, O. H., N. J. Rosebrough, A. F. Farr, and R. J.
Randall. 1951. Protein measurement with the Folin phenol reagent. J. Biol. Chem. 193: 265-275.

21. Cleland, W. W. 1964. Dithiothreitol, a new protective reagent for SH groups. Biochemistry. 3: 480-482.

22. Nakagawa, S., and W. R. Ruegamer. 1967. Properties of a rat tissue iodothyronine deiodinase and its natural inhibitor. Biochemistry. 6: 1249-1261.

23. Visser, T. J., I. Van Der Does-Tobé, R. Docter, and G. Hennemann. 1976. Subcellular localization of a rat liver enzyme converting thyroxine into tri-iodothyronine and possible involvement of essential thiol groups. Biochem. J. 157: 479-482.

24. Chopra, I. J. 1978. Sulfhydryl groups and the monodeiodination of thyroxine to triiodothyronine. Science (Wash. D. C.). 199: 904-906.

25. Maciel, R. M. B., Y. Ozawa, and I. J. Chopra. 1978. Subcellular localization of $T_{4}$ and reverse $T_{3}\left(\mathrm{rT}_{3}\right)$ outer ring monodeiodinase activities. Clin. Res. 26: 107A. (Abstr.)

26. Cavalieri, R. R., and B. Rapoport. 1977. Impaired peripheral conversion of thyroxine to triiodothyronine. Annu. Rev. Med. 28: 57-65.

27. Kaplan, M. M., M. Schimmel, and R. D. Utiger. 1977. Changes in serum 3,3',5'-triiodothyronine (reverse $T_{3}$ ) concentrations with altered thyroid hormone secretion and metabolism J. Clin. Endocrinol. Metab. 45: 447-456.

28. Nicod, P., A. Burger, G. Strauch, A. G. Vagenakis, and L. E. Braverman. 1976. The failure of physiologic doses of reverse $\mathrm{T}_{3}$ to effect thyroid-pituitary function in man. J. Clin. Endocrinol. Metab. 43: 478-481.

29. Woeber, K. A. 1977. Observations concerning the binding of L-triiodothyronine in the human polymorphonuclear leukocyte. J. Clin. Endocrinol. Metab. 44: 62-68. 